\title{
THE DETERMINANTS OF RESOURCE-PROVIDING CONTRACTS: CASE-STUDY OF THE POLISH DAIRY SECTOR
}

\author{
Liesbeth DRIES
}

\begin{abstract}
Address:
Agricultural Economics and Rural Policy Group, Wageningen University, Netherlands

*Corresponding Author; e-mail: liesbeth.dries@wur.nl
\end{abstract}

\begin{abstract}
Growth in the agri-food sector in developing and transition countries is typically impeded by major imperfections in both input and output markets. Providing resources to farmers as part of an interlinked market contract is one way of overcoming these market imperfections. This paper identifies the factors that determine access to these types of contracts for smallholders. The econometric analysis uses data from a unique survey of Polish dairy farm households during transition. The main conclusions are that competition and FDI in the processing sector are major driving forces for the spread of resource-providing contracts.
\end{abstract}

Keywords: Central and Eastern Europe, Poland, Interlinked markets, Contracts, Dairy, FDI JEL: D23, D86, F61, F63, L14, O13, Q12, Q13

\section{INTRODUCTION}

A growing number of studies discusses the importance of vertical coordination in agri-food sectors in developing and transition countries (Dries et al., 2009; Maertens and Swinnen, 2009). In this context, vertical coordination is often set up as a contractual relationship that involves farm assistance and incentive programs to overcome imperfections in input and credit markets. Several authors refer to this type of coordination as interlinked or interlocked markets because input and output markets are effectively linked through the contractual arrangement (Bardhan and Udry, 1999; Poulton et al., 1998; Winter-Nelson and Temu, 2002). Key and Runsten, 1999 use the term resource-providing contracts for contracts where the buyer of the product provides inputs, information, technology and other resources to the supplier as part of the contract.

Masakure and Henson (2005) use factor analysis to distinguish four main incentives for farmers to get involved in these contractual arrangements. Several empirical studies confirm the importance of these four factors. The first factor is input and output market uncertainty. Producers agree to contracts that provide security in terms of access to inputs and guaranteed prices and markets for outputs (Dries and Swinnen, 2010; Dries et al., 2009; Gow and Swinnen, 1998; IFAD, 2003; Poulton et al., 2004; Sadler, 2006; White and Gorton, 2006). A second factor is knowledge building and other indirect benefits. Smallholders get access to new technologies and know-how through extension services provided by the buyer (Bolwig et al., 2009; Dries and Swinnen, 2004; Minten et al., 2007; Poulton et al., 2004). Another incentive is the potential for increased income that is generated through contract production. Several studies find evidence of improved profitability and incomes for smallholders that can access high value markets through contract production (Bolwig et al., 2009; Maertens and Swinnen, 2009; Minten et al., 2007). Finally, producers can be persuaded into contract production due to intangible benefits, for example the benefits observed with other contract farmers or the satisfaction from producing for the often high-value contract market.

The impact of interlinking markets on smallholders is still heavily debated in the development economics literature. One issue is that the unequal nature of these contractual arrangements may lead to lock-in effects for producers that become dependent on their relationship with the buyer (Gereffi et al., 2005; Masakure and Henson, 2005). Another issue is that of the possible exclusion of smallholders from the benefits of interlinked contracts that are generally offered only in high value chains (Delgado, 1999; Dolan and Humphrey, 2000; Gibbon, 2003; Key and Runsten, 1999; Kirsten and Sartorius, 2002; Weatherspoon et al., 2001).

An interesting strand of the literature deals with the (un)sustainability of interlinked contract arrangements and contract breach. For example from the point of view of the supplier, contract breach may occur through delayed payments (Cungu et al., 2008; Noev et al., 2009). On the other hand, actions of the supplier can also lead to the breakdown of vertical relations. This can occur, for example, by diverting the provided inputs to alternative uses (Poulton et al., 1998) or by side-selling the final product to a buyer other than the one that delivered the resources and know-how (Poulton et al., 2004; Winter-Nelson and Temu, 2002). A number of studies find that the sustainability of interlinked contracts is affected by market conditions and other elements in 
the external environment. But these studies have reached contradicting conclusions. For example, Poulton et al. (2004) in their study of the liberalization of cotton markets in six African countries conclude that a higher degree of competition in the buyer's market leads to the breakdown of resource-providing contracts. On the other hand, Swinnen (2007) argues that a positive relationship exists between competition and vertical coordination in agri-food chains in (Eastern) Europe and Central Asia. The reason is that competition forces processors to introduce similar assistance programs for suppliers as their competitors or otherwise they risk losing their supply base. For example, Dries and Swinnen (2004) find that foreign dairy companies investing in Poland in the mid-1990s, first invested in cooling equipment at milk collection stations and provided extension services to dairy farms with respect to the handling of the milk. Domestic dairies then started to copy these practices.

Despite the attention that has been given to resource-providing contracts in the literature, there is a lack of quantitative studies that actually analyse the determinants of these contracts. This is surprising because the question has important policy implications. If the market conditions are such that private initiatives to upgrade the agri-food sector fail, policy makers have a role to play, for example, in improving the conditions for contract enforcement or otherwise to become more involved in the provision of support necessary for development.

This paper investigates the determinants of resource-providing contracts. Not only is this one of the first quantitative studies on this issue, but it also uses unique survey evidence to test the hypotheses. The next section develops a conceptual framework that discusses the determinants of resource-providing contracts. Next, the data are discussed with special attention to the selection of the survey area and its relevance for studying the research question. The econometric model in the following section relates a number of theoretical variables with an indicator that measures access to interlinked contracts. The final section provides concluding remarks and draws special attention to the policy implications of the results of the study.

\section{THE DETERMINANTS OF RESOURCE- PROVIDING CONTRACTS IN THE AGRI-FOOD SECTOR}

The conceptual framework that is used to derive the determinants of interlinked contracts is based on several strands of the literature. First, it draws on studies about the economics of sharecropping contracts and resourceproviding and production management contracts in a range of sectors (Allen and Lueck, 1993, Allen and Lueck, 1999; Fukunaga and Huffman, 2009; Key and McBride, 2003; Key and Runsten, 1999). It also uses elements from the literature on the governance of global value chains (Gereffi et al., 2005). These insights are complemented by studies discussing the importance of market conditions and the external environment in contract enforcement (Poulton et al., 2004; Swinnen, 2007; Johnson et al., 2002). Figure 1 summarizes the conceptual framework.

Three incentives are identified for establishing interlinked market contracts: necessity; profitability; enforceability. Necessity relates to the point made by Platteau (1989) that these types of contractual arrangements typically surface in recently liberalized markets, where on the one hand supply and demand for final products is in imbalance and on the other hand, specific market imperfections occur, which hinder a swift reversal of this situation. Furthermore, profitability can be an important factor in the decision to contract or not. The impact on profitability will be largely driven by the relative bargaining power of buyers and suppliers. Finally, the sustainability or enforceability of contracts will also be a crucial determinant in explaining the occurrence of contracts. The degree, to which these incentives play, will be determined by a number of factors.

First, the necessity to contract is affected by the attributes of the transaction and of the product that is being traded, the capabilities of suppliers, and the market imperfections that prevail. For standard products, such as grains, that are storable, easily described, graded and valued, the necessity to coordinate supply through contracts will be low. On the other hand, for complex products, e.g. perishables for which the quality of the product may be difficult to verify and the requirements to be fulfilled are complex, the necessity to coordinate will be high. Furthermore, the lower the capabilities of suppliers, the more likely it is that tight control and coordination of the production process and delivery become a necessity to guarantee the supply of products that meet the desired requirements (Gereffi et al., 2005).

Market imperfections can also make the provision of interlinked market contracts a necessity. In situations where suppliers have difficulties in accessing formal credit markets, processing companies (or more generally, buyers) may be well-suited to act as lenders. The reason is that they have a superior ability to monitor - through the trade-relationship - and enforce credit contracts through the extraction of debt from output deliveries (Dries and Swinnen, 2010; Fafchamps, 1997). This preferential position is even strengthened in situations where the output contract involves frequent interactions between buyer and supplier, and in situations where the supplier has made transaction-specific investments that have locked the supplier into a relationship with the buyer / lender. Other examples of market imperfections that can be resolved through resource-providing contracts are: the lack of information about production techniques, technology and quality of the final product, and absence of markets for specialized inputs. In the former case, the buyer can intervene through an extension service for suppliers. In the latter, specific input supply programs can be linked to the output contract. 


\begin{tabular}{|c|c|c|}
\hline $\begin{array}{l}\text { R } \\
\text { E } \\
\text { S } \\
\text { O } \\
\text { U } \\
\text { R } \\
\text { C } \\
\text { E } \\
\text { P } \\
\text { R } \\
\text { O } \\
\text { V } \\
\text { I } \\
\text { D } \\
\text { I } \\
\text { N } \\
\text { G }\end{array}$ & $\begin{array}{l}\text { Incentives } \\
\text { - Necessity } \\
\text { - Profitability }\end{array}$ & $\begin{array}{l}\text { Transaction attributes } \\
\text { - Information transfer } \\
\text { - Ability to codify information } \\
\text { - Transaction-specific } \\
\text { investments } \\
\text { Supplier and butyer attributes } \\
\text { - Reputation } \\
\text { - Capabilities } \\
\text { Market conditions and external } \\
\text { environment } \\
\text { - Market imperfections } \\
\text { - Structure of buyer and supplier } \\
\text { markets } \\
\text { - Legal system }\end{array}$ \\
\hline
\end{tabular}

Figure 1. The determinants of contracting

Second, profitability is determined by the respective bargaining power of the two parties to the contract. This bargaining power is affected by the degree of transactionspecific investments and the structure of the buyer and supplier markets. Owners of specialized assets weaken their bargaining position because they are locked into a specific activity (Williamson, 1975; Williamson, 1979). Both the supplier and the buyer can be locked into a specific activity or relationship because both can be required to make specific investments. The relative bargaining power will therefore depend largely on the structure of the suppliers and the buyers market. The buyer's power will be stronger if there are only few buyers but many, disorganized suppliers (Poulton et al., 2004). Alternatively, the suppliers' power will be stronger if they are well-organized or if there are only a few suppliers with a wide choice of buyers. The power of the suppliers will be strengthened even more in situations where the demand for the product exceeds the supply (Swinnen, 2007)

Platteau (1989) argues that the interlinking of input and output markets is observed most frequently in sectors that have been recently liberalized or opened up for new investments and capital flows and where the demand for the product (temporarily) exceeds supply. Swinnen (2007) refers to the term "suppliers market" in his study of interlinked market contracts in the agri-food sector in (Eastern) Europe and Central Asia. The collapse of farm output in the early years of the transition period created a situation of excess demand based on total processing capacity. This excess demand was even larger for high quality products.

Finally, the sustainability and enforceability of the contract are determined by the potential to prevent contract breach through a well-functioning court system, the reputation effect of contract breach, and the structure of buyer and supplier markets. If court litigation is a credible option in cases of contract breach, this may be an effective tool of contract enforcement and improve sustainability of the contract relationship. However, several studies find that contractual relations are stable even in the absence of formal courts or where the legal system is inadequate in enforcing contracts. In these situations, private enforcement mechanisms and reputation can act as substitutes for court enforcement (Fafchamps, 1997; Gow and Swinnen, 2001; Johnson et al., 2002). The reputation effect of contract breach requires the spread of information about loyal and disloyal parties to a contract. Furthermore, for the reputation effect to be a convincing deterrent, contract breach should have real consequences for the probability of getting a future contract with the current buyer but also with other buyers. The structure of the buyer and supplier market plays a role because it determines the alternatives that buyers and suppliers have (in case of contract breach). Where alternatives are plenty, the sustainability of contracts may be difficult because it is difficult to punish contract breach through reputation effects. The situation is exacerbated if the market structure leads to a weak bargaining position for buyers and suppliers.

\section{MATERIAL AND METHODS}

\section{Justification of the study area and sector}

For the study of the determinants of interlinked market contracts, data are used from the Polish dairy sector in the transition period. There are several reasons why the selection of this region and sector are relevant for the study of resource-providing contracts.

First, the attributes of milk make it suitable for highly coordinated transactions. Milk can be regarded as a complex product, for which quality is an important requirement (because milk quality will strongly affect the possibilities during processing and the quality of the final product). Furthermore, its perishable state makes frequent interactions between buyer and supplier necessary. As a result, the monitoring of the supplier and 
the enforcement of agreements becomes easier. Finally, milk production requires a number of transaction-specific investments (dairy cows, milking equipment, cooling tank), which may affect the relative bargaining position of buyers and suppliers.

Second, due to historical conditions, the Polish agricultural sector faced specific restrictions in terms of supplier capabilities. In contrast to most countries in Central and Eastern Europe, Polish agriculture was not extensively collectivized during the Communist era. Small-scale private farms were tolerated by the regime. Nevertheless, small-scale farms had poor access to capital and were restricted in their growth opportunities due to ideological reasons. As a result, the structure of farming remained largely unchanged under the Communist regime - with the exception of some regions in the north and the north-west of Poland where a number of large state farms had been established (Chaplin et al., 2007; Wilkin et al., 2006).

Third, dramatic institutional changes occurred since the start of transition and have significantly affected agricultural input and output markets. This led to considerable market imperfections. On the one hand, buyers of agricultural products found it increasingly difficult to access sufficient, especially high quality, supplies (see Swinnen, 2007). On the other hand, farmers found it difficult to access the necessary inputs, information, and credit to upgrade production.

As a result, several studies show that Polish dairy companies have introduced a number of policies that affected milk producers (Dries and Swinnen, 2004; Hanf and Pieniadz, 2007; Pieniadz and Hockmann, 2008; Wilkin et al., 2006). Most of these policies had either a clear quality focus (to improve milk quality) or a clear quantity focus (to increase milk production), or have targeted both outcomes. These policies have often been implemented under the form of resource-providing contracts. Nevertheless, Beckmann and Boger (2004) find that legal enforceability of contracts is lacking in Poland. Under these circumstances, it is interesting to see which suppliers have access to contracts with dairy processors (and hence resources) and which do not.

\section{Data collection process}

Data were collected in a two-stage process. In the first stage, in-depth interviews were conducted with dairy processing companies. Through the interviews qualitative insights were gained on a diverse range of topics including the structure of the supply base and assistance policies and programs with respect to suppliers. The second stage data collection was conducted through a random survey of local dairy farms, which were potential suppliers to these companies. The quantitative data that were gathered in this process will be used in the econometric analysis.

The farm-level data in the second stage were collected in the Fall of 2001. 290 dairy producing rural households were interviewed in the WarminskoMazurskie region in the north-east of Poland. Warminsko-Mazurskie is an important dairy region in
Poland. Using retrospective questions, the dataset covers information about the period $1995-2000$.

Because of the focus of the analysis, i.e. to investigate the determinants of contracts between milk producers and dairy processors, the survey concentrated on those households that delivered at least some milk to dairies. Even with this selection focus, the vast majority of the farms in the sample are very small by (West or East) European standards. About half of the farms in the sample (48\%) had less than 10 cows and $84 \%$ of the farms had less than 20 cows in 2000. The average size of dairy farms in the sample was just below 11 cows in 2000.

Comparing the sample size distribution with average farm sizes in the Warminsko-Mazurskie region, and in Poland (table 1) reveals that the sample includes a higher share of 'large farms' (more than five cows) and a smaller share of the smallest farms (between one and two cows). This observation is a result of the sample selection process which focused on selecting households that had at least some milk deliveries to dairy companies in 1995. The official Polish statistics include a large number of households that are producing milk merely for home consumption (Wilkin et al., 2006). They account for the majority of farms that have only one or two cows but are excluded from the sample.

Table 1: Share of farms by herd size in the survey, the region and Poland

\begin{tabular}{cccccccc}
\hline & \multicolumn{7}{c}{ Number of cows per farm } \\
& 1 & 2 & $3-4$ & $5-9$ & $10-19$ & $\geq 20$ & total \\
\hline sample 2000 & 5.1 & 5.9 & 10.3 & 26.9 & 35.9 & 12.4 & 100 \\
W-M $^{\text {a } 2000}$ & 22.0 & 13.8 & 19.1 & 29.1 & 13.1 & 2.9 & 100 \\
Poland 2002 & 45.9 & 22.0 & 15.1 & 10.7 & 5.1 & 1.2 & 100
\end{tabular}

${ }^{a}$ Warminsko-Mazurskie region

Source: Based on own farm survey data and (GUS, 2003)

\section{Econometric model of the determinants of contracting}

Model and variables

This section develops an econometric model to study the factors that determine access to resource-providing contracts for Polish dairy farms. Contract choice is modeled as a latent, i.e. unobserved, variable RPCONTRACT $_{\mathrm{ij}}$ * that is determined in the following model:

$\operatorname{RPCONTRACT}_{i j}{ }^{*}=\beta_{0}+\beta_{1} x_{i}+\beta_{2} y_{j}+\beta_{3} z_{i j}+\varepsilon_{i j}$

where $x_{i}$ is a vector of farm and farm operator characteristics; $y_{j}$ is a vector of dairy processor characteristics; $Z_{i j}$ is a vector of variables that identify market conditions and the external environment; and $\varepsilon_{i j}$ is a random disturbance term. It is important to note that the focus on one specific sector (dairy) makes that the transaction / product attributes are similar for all observations. This means that these determinants are 
effectively controlled for in the model. Therefore, the model only includes variables denoting supplier and buyer attributes and determinants of market conditions.

The observed dependent variable is:

$$
\operatorname{RPCONTRACT}_{i j}=\begin{aligned}
& 1, \text { if RPCONTRACT } \\
& 0, \text { if }{ }_{i j}^{*}>0
\end{aligned}
$$

Table 2 gives an overview of the prevalence of resource-providing contracts in the dataset. Several types of resources that are provided through the contracts are observed: extension services; veterinary support; input supply programs (where the cost of specialized inputs is deducted from the farmer's milk check); loans for making on-farm investments; loans for buying dairy cows; bank loan guarantees (where the dairy company provides the collateral for a bank loan).

Table 2 shows that interlinked market contracts are widespread in the Polish dairy sector. $88 \%$ of the interviewed dairy farms had access to at least one type of assistance program through their milk contract. Input supply programs are the most widespread, with $71 \%$ of the farms in the sample benefiting from such a program to access specialized inputs. Loans for general investments on the farm and for buying cows are the second most important resource that is provided. About $65 \%$ of the respondents claim to have access to these loans through their dairy company. Furthermore, 56\% of the sampled farms receive extension services from the dairy. Veterinary support and bank loan guarantees are less common but still reach about one fourth of the respondents.

Table 2: Contracts in the Polish dairy sector, share of respondents with contract

\begin{tabular}{ll}
\hline Resource-providing contract & $88 \%$ \\
\hline --- of which Extension & $56 \%$ \\
--- of which Veterinary & $23 \%$ \\
--- of which Inputs & $71 \%$ \\
--- of which Loans for on-farm investments & $64 \%$ \\
--- of which Loans for buying cows & $65 \%$ \\
--- of which Bank loan guarantee & $23 \%$ \\
\hline
\end{tabular}

Source: Own calculations based on the farm survey

The prevalence of resource-providing contracts seems to indicate that there is a necessity for the dairy company's involvement in input markets. Furthermore, the profitability and enforceability of these contracts do not cause a major impediment for contracting for the majority of farmers. However, the interesting question remains of which farms are being excluded from these programs. In the remainder of the paper the focus will be on the determinants that explain access to resourceproviding contracts for individual farms in the dataset.

The first set of independent variables are farm and farm operator characteristics and are proxies for the supplier attributes in figure 1. REPUTATION gives an indication of the stability of the relationship between the buyer and the supplier. REPUTATION is measured as the number of years (between one and five years) that the supplier has delivered milk to the same dairy processor. The hypothesis is that farmers that have a longer relationship with the dairy will have easier access to resource-providing contracts.

PRIMARY, AGE, and FARMSIZE are variables that proxy the capabilities of the farm operator. PRIMARY is a dummy that takes the value of 1 if the farm operator has not more than a primary school diploma. Farmers with low education levels are expected to have more difficulties complying with complex requirements in terms of production techniques or product specifications. They are therefore more dependent on dairy company extension and support services. AGE is measured as the age of the farm operator. Older farmers may be less up-to-date with new production techniques and may have more use of dairy companies' services. Both PRIMARY and AGE are expected to have a positive impact on RPCONTRACT.

FARMSIZE is measured as the number of cows in productive age that are present on the farm. It is expected that larger farms have less need for dairy support. On the other hand, larger farms may be in a stronger bargaining position and can negotiate more favorable contract terms. The effect of FARMSIZE on RPCONTRACT is therefore ambiguous.

Dairy processor characteristics are proxies for the buyer's attributes in figure 1 . FDI is a dummy variable that takes the value of 1 if the processor is foreignowned. On the one hand, FDI acts as an indicator of the dairy's reputation because foreign-owned dairies are seen to implement more consistent policies that reflect also on their reputation in the home market. On the other hand, FDI is a proxy for the capability of the dairy. For example, Swinnen (2007) argues that foreign direct investment has played a major role in spreading vertical coordination in transition countries because foreignowned companies typically have the necessary financial means to introduce innovative programs involving input supply and credit provision for suppliers. FDI is expected to have a positive effect on RPCONTRACT.

The vector $Z_{i j}$ includes several variables that proxy the market conditions. DISTANCE is a variable that measures the distance of the farm to the closest dairy company in $\mathrm{km}$ and gives an indication of the remoteness of the farm. More remote farmers are expected to have fewer alternatives for delivering their milk (and hence a weaker bargaining position). This positively affects the enforceability of the contract and the expected sign of DISTANCE is therefore positive.

infoPRICE is a dummy that takes the value of one if the farmer claims to have good knowledge about the milk prices that are offered by the different dairy companies in the area. This variable is used as a proxy for competition in the dairy market. This is in line with findings of Wilkin et al. (2006) who argue that price was the main incentive for milk producers in Poland to switch dairies. Similarly, infoPROGRAM is used, a dummy that takes the value of one if farmers claim to be well-informed about the assistance programs offered by other dairies in the area, as a proxy for the degree of competition in the dairy sector. On the one hand, contracts are more difficult to enforce in a competitive market (Poulton et al., 2004). On the other hand, Swinnen (2007) argues 
that farmers that are well-informed about policies and assistance programs of other dairies may also put pressure on their own dairy to introduce these programs. Therefore, the expected impact of infoPRICE and infoPROGRAM on RPCONTRACT is ambiguous.

Finally, the variable BREACH indicates the ease with which farmers can end a contract with the dairy without negative consequences. BREACH is a dummy that takes the value of one if the farmer answered yes to the question: "In your opinion, is it easy to end a contract with a dairy and start selling milk to another dairy?”. This variable should give an indication of the enforceability of contracts and the impact on RPCONTRACT is expected to be negative.

Table 3 compares the independent variables that will be used in the econometric model for the sample of farms that have access to a resource-providing contract, and those that don't. Farm operators that have a resourceproviding contract seem to be better educated and operate a slightly larger farm than other farmers. Resourceproviding contracts are also more prevalent for farmers delivering to foreign-owned dairy companies. In terms of market and external conditions, the farmers with extensive contracts are more remote, are better-informed about prices and contracts offered by other dairy companies, and find it easier to breach their contract and start delivering to another dairy. This seems to indicate that the contracted farmers have a relatively strong bargaining power vis-à-vis the dairy.

Table 3: Descriptive statistics - averages over all respondents for continuous variables, share of respondents for dummy variables

\begin{tabular}{lcc}
\hline & $\begin{array}{c}\text { Resource- } \\
\text { providing } \\
\text { contract }\end{array}$ & $\begin{array}{c}\text { No Resource- } \\
\text { providing } \\
\text { contract }\end{array}$ \\
\hline Farm and operator attributes & & 3.8 \\
REPUTATION (years) & 4 & 43 \\
AGE (years) & 44 & $39 \%$ \\
PRIMARY (dummy) & $32 \%$ & 8.5 \\
FARMSIZE (\# cows) & 10 & $32 \%$ \\
Buyer attributes & $39 \%$ & 11 \\
FDI (dummy) & 13 & $48 \%$ \\
External environment & $73 \%$ & $26 \%$ \\
DISTANCE (km) & $47 \%$ & $71 \%$ \\
InfoPRICE (dummy) & $76 \%$ & \\
InfoPROGRAM & & \\
(dummy) & & \\
BREACH (dummy) & & \\
\hline
\end{tabular}

Source: Own calculations based on the farm survey

\section{RESULTS}

The model specified in the previous section is estimated using a logit regression technique. Preliminary tests using the full model indicated that there was a problem of multicollinearity between a number of variables. Before turning to the results, pairwise correlation coefficients for the independent variables were estimated to rule out excessive degrees of multicollinearity which affect the outcome of the model. Table 4 gives an overview of the variables that showed significant correlation coefficients (at the $1 \%$ level).

Table 4: Correlation matrix

\begin{tabular}{ll}
\hline Correlation coefficients significant at 1\% level: & Correlation: \\
\hline REPUTATION and DISTANCE & Negative \\
DISTANCE and FDI & Positive \\
AGE and PRIMARY & Positive \\
PRIMARY and InfoPRICE & Negative \\
PRIMARY and InfoPROGRAM & Negative \\
InfoPRICE and InfoPROGRAM & Positive \\
\hline
\end{tabular}

Source: Own calculations based on the farm survey

First, REPUTATION and DISTANCE show a strong negative correlation. This seems to indicate that more remote farmers are less loyal and have switched dairy companies more frequently in recent years. It should be noted that the switch between dairy companies can also be a result of the closure of a nearby dairy. This can then also explain the negative relation between the distance to the closest dairy and the number of years that the farmer has supplied to the current dairy. Furthermore, DISTANCE and FDI have a highly significant positive correlation coefficient. In other words, more remote farmers are more likely to deliver their milk to foreignowned dairy companies. Because of the strong correlation of DISTANCE with both REPUTATION and FDI, it was decided to exclude DISTANCE as an explanatory variable from the regression model.

Next, strong positive correlation between AGE and PRIMARY indicates that older farmers are also lesseducated. Furthermore, there is a strong negative correlation between the level of education (PRIMARY) and infoPRICE and infoPROGRAM. In other words, less-educated farmers are less informed about the prices and programs that prevail in other dairies in the region. Due to this correlation effect, it was decided to exclude PRIMARY from the econometric analysis.

Finally, there exists strong correlation between the variables infoPRICE and infoPROGRAM. Farmers that are well-informed about the prices in other dairies, also seem to have information about the assistance that these dairies provide to their farmers. Due to this correlation, we were unable to use infoPRICE and infoPROGRAM simultaneously in the model.

The results are reported in tables 5 and 6 . Table 5 shows the coefficient and significance level of each of the independent variables that are used to explain the access to at least one of the assistance programs that are provided as part of a resource-providing contract. Table 6 summarizes the results for the regression models that use specific resources that are provided in the contract as the dependent variable. Note that the independent variables shown in table 5 are also used in the regression models in table 6 , but that only significant explanatory variables are reported.

An interesting result that is consistently found in all model specifications is that farm and operator attributes (REPUTATION, AGE, FARMSIZE) are not significant in explaining the access to resource-providing contracts. The result that farm size is not significant is especially interesting. It shows that - in the context of this study - 
large farms are not in a preferential position compared to smallholders, to access the assistance programs provided by dairy companies.

Table 5: Determinants of resource-providing contracts Dependent Variable: RPCONTRACT - 247 observations Coefficient $\quad \mathrm{z}-\quad \mathrm{P}>|\mathrm{z}|$ value

\begin{tabular}{lrrr}
\hline Farm and operator attributes & & & \\
REPUTATION & 0.077 & 0.75 & 0.452 \\
AGE & 0.012 & 0.62 & 0.532 \\
FARMSIZE & 0.044 & 0.97 & 0.330 \\
Buyer attributes & & & \\
FDI & 0.352 & 0.84 & 0.401 \\
Market and external conditions & & & \\
InfoPRICE & 1.031 & 2.57 & $0.010^{* * *}$ \\
BREACH & 0.302 & 0.69 & 0.491 \\
Constant & -0.256 & -0.24 & 0.812 \\
\hline
\end{tabular}

Significance tests: * 10\%; ** 5\%;*** $1 \%$ significance level

Source: Own calculations based on the farm survey

Table 6: Determinants of resource-providing contracts ctd.

\begin{tabular}{|c|c|}
\hline Dependent Variable & Significant results \\
\hline Extension & InfoPRICE (++) \\
\hline Veterinary & $\begin{array}{l}\text { InfoPROGRAM (+); } \\
\text { FDI (--) }\end{array}$ \\
\hline Inputs & $\begin{array}{l}\text { InfoPRICE }(+++) \\
\text { FDI }(+++)\end{array}$ \\
\hline $\begin{array}{l}\text { Loans for on-farm } \\
\text { investments }\end{array}$ & FDI $(++)$ \\
\hline Loans for buying cows & - \\
\hline Bank loan guarantee & InfoPRICE (++) \\
\hline
\end{tabular}

Significance tests: $(+),(++),(+++)$ significantly positive respectively at $10 \%$; $5 \%$; $1 \%$ significance level; (-), (--), (--) significantly negative respectively at $10 \%$; $5 \%$; $1 \%$ significance level.

Source: Own calculations based on the farm survey

A second result is that infoPRICE (and in one case infoPROGRAM) has a significantly positive effect on the likelihood of farmers to access resource-providing contracts. This result holds for RPCONTRACT in general, but also for access to extension services, veterinary support, input supply programs, and access to bank loan guarantees from the dairy. Being wellinformed about the pricing policies and assistance programs of other dairies plays an important role in securing assistance from the dairy that a farmer delivers to. This result seems to support findings by Swinnen (2007) who argues that competition between agri-food processors is an important driver for spreading vertical coordination with suppliers throughout the industry.

Finally, delivering milk to a foreign-owned dairy company rather than to a domestic processor is also an important determinant for explaining access to resourceproviding contracts. The significantly negative coefficient for FDI in the regression model explaining veterinary support seems to indicate that foreign-owned firms are less inclined to offer veterinary services to their suppliers. However, FDI has a significantly positive effect on the likelihood to enroll in an input supply program and to access loans for on-farm investments. This result may not be surprising because setting up an input supply program and providing loans are typically the programs that require more extensive financial means from the dairy company. The result is therefore in line with our hypothesis that - in the context of a financially constrained domestic sector - "the deep pockets" of foreign-owned firms increase the likelihood of the establishment of resource-providing contracts.

\section{DISCUSSION AND CONCLUSIONS}

Interlinking markets is an important concept in the context of developing and transition countries, which are typically characterized by imperfections in both the input and the output market. Providing resources to farmers as part of a contract that specifies the procurement of output is one way of overcoming these market imperfections. The conditions under which interlinked market contracts prevail are therefore interesting from a policy point of view. This paper uses unique survey evidence to answer the question of what the determinants are of the establishment of these interlinked market contracts.

The data that are used to answer this question are collected in a processor and farmer survey in the dairy sector in Poland in 2001. At the time of the survey, the Polish dairy sector was characterized by problems related to the unfavorable structure of the farming sector that led to poor capabilities of milk producers, and numerous imperfections in markets for inputs, credit, technologies and know-how. The majority of these problems can be seen as the sector's legacy of the Communist era and transition.

The econometric evidence in this paper leads to two interesting conclusions with respect to the determinants of the establishment of interlinked markets. First, the results show that farmers that are better-informed about prices and assistance programs offered by other dairies in the area are more likely to have access to resources provided through the contract with their dairy. Generalizing this result leads to the conclusion that more competition between dairy processors positively affects the development of resource-providing contracts, and hence the access to resources for smallholders in an environment dominated by input market imperfections. This is in line with findings by Swinnen (2007) who claims that competition leads to more vertical coordination.

Linked to this result, it should be noted that being informed about dairy policies and prices was strongly correlated with the level of education of the farm operator. More precisely, less-educated farmers were also less likely to have access to information from other dairies. This point should be taken into account when formulating policy advice. If being less educated prevents farmers from accessing or interpreting information relevant to their operation, and this in turn leads to these farmers being excluded from contracts that alleviate market imperfections, focusing public programs (for example extension or information provision) on this aspect may lead to a more widespread inclusion of the vulnerable farm population. 
A second result is that farmers delivering to foreignowned firms have better access to resource-providing contracts than their counterparts that deliver to the domestic sector. This is in line with the argument that foreign-owned firms have the necessary financial means - that may be lacking in the domestic sector, especially in developing and transition countries - to set-up assistance programs for their suppliers. This result provides an important contribution to the debate of whether FDI can accelerate or depress growth in developing countries. This study concludes that, under certain conditions, foreign investments should be welcomed by developing countries' policy makers as they can stimulate growth in the domestic sector by alleviating the constraints of persisting market imperfections.

Finally, a note on the relevance and generalizability of the conclusions of this study. Despite the focus on a limited study area (Poland), the results are more widely applicable and relevant for other developing and transition countries. First, the specific characteristics of the Polish dairy sector in the period of the study, show strong similarities with the agri-food sector in developing countries, i.e. small-scale operations, undercapitalization and a strong need for restructuring (Wilkin et al., 2006). Furthermore, the prevalence of resource-providing contracts is not limited to the study area and has been observed in the agri-food sector in numerous countries and sectors (see for example Dolan and Humphrey, 2000; Fafchamps, 1997; Maertens and Swinnen, 2009 and Minten et al., 2007 for studies on resourceproviding contracts in African countries and Dries et al., 2009; Noev et al., 2009 and White and Gorton, 2006 for examples of studies in transition countries other than Poland). These studies show that resource-providing contracts are also observed in countries where the farm structure is very different from that in Poland.

Since the time of the study, the context in which the Polish dairy sector operates has changed dramatically, not in the least through the process of EU accession. This had a number of important implications such as the stabilization of milk prices, the introduction of milk production quota and the implementation of stringent policies related to the quality and handling of raw materials. Especially the latter reinforced the need for strong vertical relationships in the dairy chain to comply with higher standards. Dries et al. (2011) show that the resource-providing contracts that were introduced in the dairy sector in the late 1990s still exist after Poland joined the EU. However, some new elements of support had been introduced. For example, dairy companies started to provide loans to farmers for buying extra milk quota. With the continued development of the Polish dairy sector and further changes in the external environment, we can expect also a continuous process of transition in observed contractual arrangements and support systems in the Polish dairy sector.

\section{REFERENCES}

Allen, D.W., Lueck, D., 1993. Transaction costs and the design of cropshare contracts. Rand Journal of Economics 24, 78-100.

http://dx.doi.org/10.2307/2555954

Allen, D.W., Lueck, D., 1999. The role of risk in contract choice. Journal of Law Economics \& Organization 15, 704-736.

http://dx.doi.org/10.1093/jleo/15.3.704

Bardhan, P.K., Udry, C., 1999. Development Microeconomics. Clarendon Press, Oxford, UK. http://dx.doi.org/10.1093/0198773714.001.0001

Beckmann, V., Boger, S., 2004. Courts and contract enforcement in transition agriculture: theory and evidence from Poland. Agricultural Economics 31, 251263.

http://dx.doi.org/10.1111/j.1574-0862.2004.tb00262.x

Bolwig, S., Gibbon, P., Jones, S., 2009. The Economics of Smallholder Organic Contract Farming in Tropical Africa. World Development 37, 1094-1104.

http://dx.doi.org/10.1016/j.worlddev.2008.09.012

Chaplin, H., Gorton, M., Davidova, S., 2007. Impediments to the diversification of rural economies in Central and Eastern Europe: Evidence from small-scale farms in Poland. Regional Studies 41, 361-376.

http://dx.doi.org/10.1080/00343400701282129

Cungu, A., Gow, H., Swinnen, J.F.M., Vranken, L., 2008. Investment with weak contract enforcement: evidence from Hungary during transition. European Review of Agricultural Economics 35, 75-91.

http://dx.doi.org/10.1093/erae/jbn001

Delgado, C., 1999. Sources of growth in smallholder agriculture in sub-Saharan Africa: The role of vertical integration of smallholders with processors and marketers of high value-added items. Agrekon 38, 165189.

http://dx.doi.org/10.1080/03031853.1999.9524913

Dolan, C., Humphrey, J., 2000. Governance and trade in fresh vegetables: The impact of UK supermarkets on the African horticulture industry. Journal of Development Studies 37, 147-176.

http://dx.doi.org/10.1080/713600072

Dries, L., Swinnen, J.F.M., 2004. Foreign direct investment, vertical integration, and local suppliers: Evidence from the Polish dairy sector. World Development 32, 1525-1544.

http://dx.doi.org/10.1016/j.worlddev.2004.05.004

Dries, L., Swinnen, J.F.M., 2010. The impact of interfirm relationships on investment: Evidence from the Polish dairy sector. Food Policy 35, 121-129.

http://dx.doi.org/10.1016/j.foodpol.2009.11.005

Dries, L., Falkowski, J., Malak-Rawlikowska, A. and Milczarek-Andrzejewska, D., 2011, Public Policies and Private Initiatives in Transition: Evidence from the Polish Dairy Sector, Post-Communist Economies, 23(2), pp. 219-236.

http://dx.doi.org/10.1080/14631377.2011.570051

Dries, L., Germenji, E., Noev, N. and J.F.M. Swinnen, 2009, Farmers, Vertical Coordination, and the Restructuring of Dairy Supply Chains in Central and 
Eastern Europe, World Development, 37(11), pp. 17421758.

http://dx.doi.org/10.1016/j.worlddev.2008.08.029

Fafchamps, M., 1997. Trade credit in Zimbabwean manufacturing. World Development 25, 795-815.

http://dx.doi.org/10.1016/S0305-750X(96)00134-9

Fukunaga, K., Huffman, W.E., 2009. The Role of Risk and Transaction Costs in Contract Design: Evidence from Farmland Lease Contracts in US Agriculture. American Journal of Agricultural Economics 91, 237249.

http://dx.doi.org/10.1111/j.1467-8276.2008.01164.x

Gereffi, G., Humphrey, J., Sturgeon, T., 2005. The governance of global value chains. Review of International Political Economy 12, 78-104.

http://dx.doi.org/10.1080/09692290500049805

Gibbon, P., 2003. Value-chain Governance, Public Regulation and Entry Barriers in the Global Fresh Fruit and Vegetable Chain into the EU Development Policy Review 21, 615-625.

http://dx.doi.org/10.1111/j.1467-8659.2003.00227.x

Gow, H.R., Swinnen, J.F.M., 1998. Up- and downstream restructuring, foreign direct investment, and hold-up problems in agricultural transition. European Review of Agricultural Economics 25, 331-350.

http://dx.doi.org/10.1093/erae/25.3.331

Gow, H.R., Swinnen, J.F.M., 2001. Private enforcement capital and contract enforcement in transition economies. American Journal of Agricultural Economics 83, 686690.

http://dx.doi.org/10.1111/0002-9092.00191

Hanf, J.H., Pieniadz, A., 2007. Quality management in supply chain networks - The case of Poland. International Food and Agribusiness Management Review 10, 102128.

http://www.ifama.org/files/20061018_formatted.pdf

IFAD, 2003. Agricultural Marketing Companies as Sources of Smallholder Credit in Eastern and Southern Africa. Experiences, Insights and Potential Donor Role. IFAD, Rome.

http://www.ifad.org/ruralfinance/policy/pf.pdf

Johnson, S., McMillan, J., Woodruff, C., 2002. Courts and relational contracts. Journal of Law Economics \& Organization 18, 221-277.

http://dx.doi.org/10.1093/jleo/18.1.221

Key, N., McBride, W., 2003. Production contracts and productivity in the US hog sector. American Journal of Agricultural Economics 85, 121-133.

http://dx.doi.org/10.1111/1467-8276.00107

Key, N., Runsten, D., 1999. Contract farming, smallholders, and rural development in Latin America: The organization of agroprocessing firms and the scale of outgrower production. World Development 27, 381-401. http://dx.doi.org/10.1016/S0305-750X(98)00144-2

Kirsten, J., Sartorius, K., 2002. Linking agribusiness and small-scale farmers in developing countries: is there a new role for contract farming? Development Southern Africa 19, 503-529.

http://dx.doi.org/10.1080/0376835022000019428
Maertens, M., Swinnen, J.F.M., 2009. Trade, Standards, and Poverty: Evidence from Senegal. World Development 37, 161-178.

http://dx.doi.org/10.1016/j.worlddev.2008.04.006

Masakure, O., Henson, S., 2005. Why do small-scale producers choose to produce under contract? Lessons from nontraditional vegetable exports from Zimbabwe. World Development 33, 1721-1733.

http://dx.doi.org/10.1016/j.worlddev.2005.04.016

Minten, B., Randrianarison, L., Swinnen, J., 2007. Spillovers from high-value agriculture for exports on land use in developing countries: evidence from Madagascar. Agricultural Economics 37, 265-275.

http://dx.doi.org/10.1111/j.1574-0862.2007.00273.x

Noev, N., Dries, L., Swinnen, J.F.M., 2009. Institutional Change, Contracts, and Quality in Transition Agriculture Evidence from the Bulgarian Dairy Sector. Eastern European Economics 47, 62-85.

http://dx.doi.org/10.2753/EEE0012-8775470404

Pieniadz, A., Hockmann, H., 2008. Factors Driving Quality Standard Compliance in the Polish Dairy Sector.

Atlantic Economic Journal 36, 41-52.

http://dx.doi.org/10.1007/s11293-007-9101-y

Platteau, J.P., 1989. Penetration of capitalism and persistence of small-scale organizational forms in thirdworld fisheries. Development and Change 20, 621-651. http://dx.doi.org/10.1111/j.1467-7660.1989.tb00360.x

Poulton, C., Dorward, A., Kydd, J., 1998. The revival of smallholder cash crops in Africa: Public and private roles in the provision of finance. Journal of International Development 10, 85-103.

http://dx.doi.org/10.1002/(SICI)1099-

1328(199801)10:1\%3C85::AID-JID502\%3E3.0.CO;2-V

Poulton, C., Gibbon, P., Hanyani-Mlambo, B., Kydd, J., Maro, W., Larsen, M.N., Osorio, A., Tschirley, D., Zulu, B., 2004. Competition and coordination in liberalized African cotton market systems. World Development 32, 519-536.

http://dx.doi.org/10.1016/j.worlddev.2003.10.003

Sadler, M., 2006. Vertical coordination in the cotton supply chains in Central Asia, in: Swinnen, J. (Ed.), The dynamics of vertical coordination in agrifood chains in Eastern Europe and Central Asia: implications for policy and World Bank operations. ECSSD, Europe and Central Asia, The World Bank, Washington D.C.

http://siteresources.worldbank.org/INTRANETTRADE/ Resources/Topics/Standards/Swinnen.pdf

Swinnen, J., 2007. Global supply chains, standards and the poor. CABI Publishing, Oxon, U.K.

Weatherspoon, D., Cacho, J., Christy, R., 2001. Linking globalization, economic growth and poverty: Impacts of agribusiness strategies on sub-Saharan Africa. American Journal of Agricultural Economics 83, 722-729.

http://dx.doi.org/10.1111/0002-9092.00197

White, J., Gorton, M., 2006. A comparative study of agri-food chains in Moldova, Armenia, Georgia, Russia and Ukraine, in: Swinnen, J. (Ed.), The dynamics of vertical coordination in agrifood chains in Eastern Europe and Central Asia: implications for policy and World Bank operations. ECSSD, Europe and Central Asia, The World Bank, Washington D.C. 
http://siteresources.worldbank.org/INTRANETTRADE/ Resources/Topics/Standards/Swinnen.pdf

Wilkin, J., Milczarek, D., Falkowski, J., MalakRawlikowska, A., 2006. The Dairy Sector in Poland, Agrifood Sector Series. Regoverning Markets Project.

http://pubs.iied.org/pdfs/G03290.pdf

Williamson, O.E., 1975. Markets and hierarchies: Analysis and antitrust implications. The Free Press, New York.
Williamson, O.E., 1979. Transaction cost economics: The governance of contractual relations. Journal of Law and Economics 22, 3-61.

http://dx.doi.org/10.1086/466942

Winter-Nelson, A., Temu, A., 2002. Institutional adjustment and transaction costs: Product and inputs markets in the Tanzanian coffee system. World Development 30, 561-574.

http://dx.doi.org/10.1016/S0305-750X(01)00126-7 